\title{
The influence of prices, facilities, and promotions on customer satisfaction at Grand Darmo Suite Surabaya
}

\author{
Harun Al Rasyid Oktabar Sutomo \\ Narotama University Indonesia \\ harunalrasyid809@gmail.com
}

\begin{abstract}
Grand Darmo Suite Surabaya Hotel has many determinants in customer satisfaction, these factors are Price, Facilities, and Promotion. And these factors will be examined statistically which aims to determine how much influence the price, facilities, and promotions on customer satisfaction Grand Darmo Suit e Surabaya Hotel. The population in this study were guests of the Grand Darmo Suite Hotel Surabaya, who were staying at this hotel. While the determination of samples on customer satisfaction will use a purposive sampling technique, and the data used is primary data with a sample of 85 respondents. The analysis technique used is multiple linear regression analysis. Based on the results of the study indicate that the variables of price, facilities, and promotions have a significant effect on customer satisfaction. And in terms of the closeness between prices, facilities, and promotions on customer satisfaction, the Grand Darmo Suite Surabaya Hotel has a fairly high relationship.
\end{abstract}

Keywords: Price, Facilities, Promotion, and Customer Satisfaction

\section{INTRODUCTION}

In modern times the hotel is not only a means of staying and resting, but is a business tool for business people who often travel outside the city. Even being a meeting place for meetings both personally and between companies and companies is also used as a means of marriage, halal bi halal, birthday party, iftar. Starting from jasmine-class hotels to 5-star hotels currently competing in terms of promotions and prices to attract consumers so that they can use these services. Not just promotions and prices, facilities are no less interesting. For this reason, service providers (hotels) began to develop existing facilities in the company in order to get satisfaction for their customers who stayed at the hotel, while the facilities at the hotel include: Lobby Lounge, ATM Center, Cake \& Bakery shop, BAR \& Lounge, Restaurant, Swimming Pool, WiFi Hight Speed, Fitness center, coffee shop, ballroom, meeting room, massage \& spa center, 24 hour clinic, security, suttle vehicle.

The location of this hotel is very strategic, Grand Darmo Suite Surabaya Hotel stands right behind the famous park in Surabaya, namely Bungkul Park Surabaya, located next to Soemitro air force hospital, and more precisely on J1 Progo No 1-3 Surabaya.

Table 1

\begin{tabular}{cccc}
\hline Month & Income & $\begin{array}{c}\text { number of } \\
\text { rooms sold }\end{array}$ & Visitor \\
\hline August & $\mathrm{Rp}$ & 4.100 & 9.540 \\
September & $\begin{array}{c}1.900 .000 .000 \\
\mathrm{Rp}\end{array}$ & 4.000 & 10.120 \\
October & $\begin{array}{c}2.100 .000 .000 \\
\mathrm{Rp}\end{array}$ & 3.900 & 8.760 \\
& 1.800 .000 .000 & & \\
\hline
\end{tabular}


Based on the description of the background above, the researcher created a research theme entitled "THE EFFECT OF PRICES, FACILITIES AND PROMOTIONS ON CUSTOMER SATISFACTION IN THE GRAND DARMO SUITE HOTEL SURABAYA".

\subsection{Formulation of the problem}

Based on this background, the researcher gets the problem and formulates it as follows:

1. Do prices, facilities and promotions have a significant simultaneous effect on customer satisfaction?

2. Do prices, facilities, and promotions have a significant partial effect on customer satisfaction?

\subsection{Objectives and Benefits of Research}

Research purposes

1. To analyze the influence of the partial variable prices, facilities, and promotions on customer satisfaction who stayed at the Grand Darmo Suite Hotel Surabaya.

2. To analyze the effect of simultaneously variable prices, facilities, and promotions on customer satisfaction staying at the Grand Darmo Suite Hotel Surabaya.

\subsection{Benefits of research}

a. For academics,

Research The influence of prices, facilities and promotions on customer satisfaction is intended to increase knowledge for academics who are interested in exploring the field of marketing.

b. For companies,

The results of this study can be used as input in terms of the influence of prices, facilities and promotions, by conducting this research can contribute to the thought of how much influence the price, facilities and promotion policies have on customer satisfaction at the Grand Darmo Suite Hotel Surabaya.

c. For Authors,

This research is a requirement for writers to complete one-year education programs. And it is expected to be able to add knowledge and insight into the influence of prices, facilities and promotions on customer satisfaction, especially in service.

\section{BASIC THEORY}

\subsection{Price}

In a narrow sense, price is an amount that is billed for a product or service. For a broader meaning, price is the sum of all the values that have been given by customers to benefit from owning or using a product or service [1].

there are 4 price indicators [2], namely:

1. Price affordability

2. Price compatibility with product quality

3. Price competitiveness

4. Price compatibility with benefits

\subsection{Facilities}

Facilities are as much physical power as there should be before a service that can be offered to consumers. Facilities can also be anything that can make it easier for consumers to obtain satisfaction[3]. Facilities are physical resources that must exist before a service will be offered to consumers. [4] . Facility variable indicator:

1. Space planning

2. Equipment / furniture

3. Light and color

4. Supporting elements (musholla, atm center, parking lot)

5. Messages conveyed with visual appearance media (images \& philosophies on the walls of the corridor and restaurant). 


\subsection{Promotion}

Promotion is a form of marketing communication. What is marketing communication? Marketing communication is all marketing activities that attempt to disseminate information, influence or persuade, and or to increase the target market share of the company and its products in order to be ready to receive, buy, and loyal to the products that the company has to offer [5].

Promotion is an activity carried out by a company to highlight the characteristics of its products that persuade target consumers to buy their products [6].

Promotional indicators:

1. Quality promotion

2. Promotion quantity

3. Promotion time

4. Accuracy or suitability of promotional objectives is a factor needed to achieve the desired target of the company.

5. Frequency of promotion

\subsection{Customer satisfaction}

Customer satisfaction is a feeling of pleasure or disappointment of someone who has compared the performance or results that he has felt compared to his expectations. Satisfaction is a kind of comparison between experience and evaluation results, can produce a feeling of being spiritually comfortable, but not only comfortable because it is expected or imagined, satisfied customer dissatisfaction is not an emotion but an evaluation of emotions [6].

Consumer satisfaction is a full-time evaluation where alternatives that are chosen at least will yield results (outcomes) equal or exceed consumer expectations [7] . Variable indicators of customer satisfaction:

1. Availability recommend

2. Conformity of expectations

3. Interest in returning

\section{CONCEPTUAL FRAMEWORK}

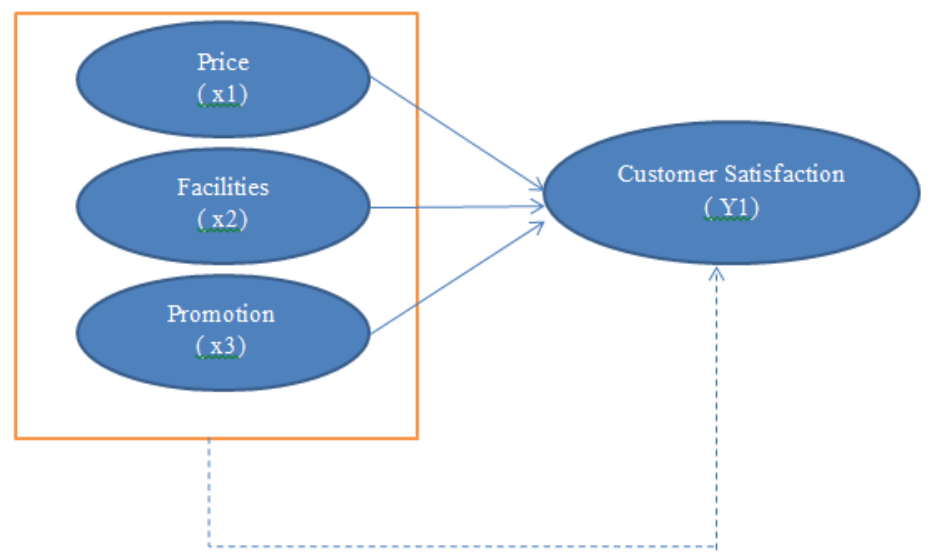

Figure 1 : Conceptual Framework

\section{HYPOTHESIS}

The hypothesis is a temporary answer or conclusion that is taken to answer the problems raised in the study [8].

The hypothesis proposed in this study is

H1. There are variable prices, facilities, and promotions that have a significant simultaneous effect on customer satisfaction at the Grand Darmo Suite Surabaya hotel.

$\mathrm{H} 2$. There is a price variable that has a significant effect partially on the customer satisfaction of the Grand Darmo Suite Surabaya hotel. 
H3. There are facilities variables that have a significant effect partially on the customer satisfaction of the Grand Darmo Suite Surabaya hotel.

H4. There is a promotion variable that has a significant effect partially on the customer satisfaction of the Grand Darmo Suite Surabaya hotel.

\section{RESEARCH METHODOLOGY}

\subsection{Population and Sampling Techniques}

The population in this study was customers of the Grand Darmo Suite Surabaya Hotel. Sampling is done by purposive sampling technique. The sample used in this study is the customers of Surabaya Grand Darmo Suite who stayed at this hotel.

\subsection{Analysis of Reliability and Validity \\ Test Reliability \\ Test Validity}

\subsection{Data Analysis}

Multiple Linear Regression Test

How to know the influence of independent variables with depedent. This method is commonly referred to as forecast, because it can estimate the good or bad variable $\mathrm{X}$ for the rise or fall of the $\mathrm{Y}$ variable, and vice versa. According to Umar (2010):

$$
\mathrm{Y}=\mathrm{a}+b_{1} x_{1}+b_{2} x_{2}+b_{3} x_{3}+\mathrm{e}
$$

5.4 Testing of Research Hypotheses

Simultaneous Test (F-Test / ANOVA)

Partial Test (t Test)

R-Square Analysis $\left(R^{2}\right)$

5.5 Classic assumption test

Multicollinearity

Heteroscedasticity

Normality

\section{RESEARCH RESULTS AND DISCUSSION}

6.1 Reliability Test

Table 2

From the results of the reliability test the alpha value below is obtained

\begin{tabular}{lcccc}
\hline & $\begin{array}{c}\text { Scale Mean if } \\
\text { Item Deleted }\end{array}$ & $\begin{array}{c}\text { Scale Variance } \\
\text { if Item Deleted }\end{array}$ & $\begin{array}{c}\text { Corrected } \\
\text { Item-Total } \\
\text { Correlation }\end{array}$ & $\begin{array}{c}\text { Cronbach's } \\
\text { Alpha if Item } \\
\text { Deleted }\end{array}$ \\
\hline $\mathbf{x 1 . 1}$ & 53.1467 & 159.559 & .833 & .978 \\
$\mathbf{x 1 . 2}$ & 53.4667 & 156.009 & .863 & .978 \\
$\mathbf{x 1 . 3}$ & 53.7200 & 155.015 & .840 & .978 \\
$\mathbf{x 1 . 4}$ & 53.8667 & 153.712 & .907 & .977 \\
$\mathbf{x 2 . 1}$ & 54.0400 & 156.147 & .942 & .977 \\
$\mathbf{x 2 . 2}$ & 53.2933 & 155.534 & .901 & .977 \\
$\mathbf{x 2 . 3}$ & 53.4933 & 161.713 & .826 & .978 \\
$\mathbf{x 2 . 4}$ & 54.0667 & 153.279 & .904 & .977 \\
$\mathbf{x 2 . 5}$ & 53.9200 & 156.912 & .923 & .977 \\
$\mathbf{x 3 . 1}$ & 53.5467 & 162.008 & .858 & .978 \\
$\mathbf{x 3 . 2}$ & 54.2000 & 161.973 & .700 & .980 \\
$\mathbf{x 3 . 3}$ & 54.0267 & 157.513 & .921 & .977 \\
$\mathbf{x 3 . 4}$ & 53.4667 & 153.360 & .911 & .977 \\
\hline
\end{tabular}




\begin{tabular}{lllll}
\hline $\mathbf{x 3 . 5}$ & 53.4000 & 164.784 & .825 & .979 \\
$\mathbf{y 1 . 1}$ & 53.8933 & 157.367 & .734 & .979 \\
$\mathbf{y 1 . 2}$ & 53.5467 & 147.630 & .901 & .978 \\
$\mathbf{y 1 . 3}$ & 53.5467 & 156.143 & .840 & .978 \\
\hline
\end{tabular}

6.2 Validity test

Table 3

\begin{tabular}{|c|c|c|c|}
\hline Item Pernyataan & $\boldsymbol{r}_{\text {hitung }}$ & $r_{\text {tabel }}$ & Keterangan \\
\hline \multicolumn{4}{|l|}{ Harga $(X 1)$} \\
\hline H1 & 0,833 & 0,180 & Valid \\
\hline $\mathbf{H 2}$ & 0,863 & 0,180 & Valid \\
\hline H3 & 0,840 & 0,180 & Valid \\
\hline H4 & 0,907 & 0,180 & Valid \\
\hline \multicolumn{4}{|l|}{ Fasilitas (X2) } \\
\hline F1 & 0,942 & 0,180 & Valid \\
\hline $\mathbf{F} 2$ & 0,901 & 0,180 & Valid \\
\hline F3 & 0,826 & 0,180 & Valid \\
\hline F4 & 0,904 & 0,180 & Valid \\
\hline F5 & 0,923 & 0,180 & Valid \\
\hline \multicolumn{4}{|l|}{ Promosi (X3) } \\
\hline P1 & 0,858 & 0,180 & Valid \\
\hline $\mathbf{P 2}$ & 0,700 & 0,180 & Valid \\
\hline P3 & 0,921 & 0,180 & Valid \\
\hline P4 & 0,911 & 0,180 & Valid \\
\hline P5 & 0,825 & 0,180 & Valid \\
\hline \multicolumn{4}{|c|}{$\begin{array}{l}\text { Kepuasan Pelanggan } \\
\text { (Y) }\end{array}$} \\
\hline KP1 & 0,734 & 0,180 & Valid \\
\hline KP2 & 0,901 & 0,180 & Valid \\
\hline KP3 & 0,840 & 0,180 & Valid \\
\hline
\end{tabular}

From the data above states that of the 85 items of statements given to 85 respondents found the value of Corrected Item-Total Correlation is greater than the value of $r_{-}$tabel $(0.180)$ which means the data is valid.

\section{DATA ANALYSIS}

Multiple Linear Regression Test

\begin{tabular}{cccccc}
\hline Model & \multicolumn{2}{c}{$\begin{array}{c}\text { Unstandardized } \\
\text { Coefficients }\end{array}$} & $\begin{array}{c}\text { Standardized } \\
\text { Coefficients }\end{array}$ & $\mathbf{t}$ & Sig. \\
\hline $\mathbf{1}$ (Constant) & $\mathrm{B}$ & Std. Error & Beta & & \\
$\mathbf{X 1}$ & .128 & .140 & & .911 & .365 \\
$\mathbf{X} 2$ & .232 & .079 & .228 & 2.947 & .004 \\
$\mathbf{X 3}$ & .564 & .064 & .597 & 8.881 & .000 \\
& .176 & .067 & .185 & 2.638 & .010 \\
\hline
\end{tabular}


Based on the results of calculations in the table above, the multiple linear regression equation is obtained as follows:

$$
\mathrm{Y}=0,128+0,232 \mathrm{X} 1+0,564 \mathrm{X} 2+0,176 \mathrm{X} 3+0,471
$$

\section{TESTING OF RESEARCH HYPOTHESIS}

8.1 Test of determination $R^{2}$

Table 5

\begin{tabular}{lllll}
\hline Model & $\mathrm{R}$ & R Square & $\begin{array}{l}\text { Adjusted R } \\
\text { Square }\end{array}$ & $\begin{array}{l}\text { Std. Error of the } \\
\text { Estimate }\end{array}$ \\
\hline 1 & $.920^{\mathrm{a}}$ & .846 & .839 & .36437 \\
\hline
\end{tabular}

The correlation coefficient $\left(R^{2}\right)$ in this study with calculation through SPSS 18 obtained an $R^{2}$ value of 0.839 which means the influence of the independent variable is $83.9 \%$, the remaining $16.1 \%$ is caused by other variables not examined.

Table 6

8.2 Test F (Simultaneous)

\begin{tabular}{cccccc}
\hline Model & $\begin{array}{c}\text { Sum of } \\
\text { Squares }\end{array}$ & df & $\begin{array}{c}\text { Mean } \\
\text { Square }\end{array}$ & F & Sig. \\
\hline Regression & 66.767 & 3 & 22.256 & 180.424 & $.000^{a}$ \\
Residual & 9.992 & 81 & .123 & & \\
Total & 76.759 & 84 & & & \\
\hline
\end{tabular}

Due to $\mathrm{F}$ count $>\mathrm{F}$ table $(180,424>2.72), \mathrm{H} 1$ is accepted at the $5 \%$ significance level. The data can be concluded that all independent variables (Price (X1), Facilities (X2), Promotion (X3)) simultaneously affect the dependent variable Y (Customer Satisfaction). Then the first hypothesis can state that "Price, Facilities, and Promotion variables have a significant effect on Customer Satisfaction in the Grand Darmo Suite Surabaya hotel which is proven empirically.

\section{Table 7}

8.3 T test (partial)

\begin{tabular}{cccccc}
\hline Model & \multicolumn{2}{c}{$\begin{array}{c}\text { Unstandardized } \\
\text { Coefficients }\end{array}$} & $\begin{array}{c}\text { Standardized } \\
\text { Coefficients }\end{array}$ & t & Sig. \\
\hline $\mathbf{1}$ (Constant) & B & Std. Error & Beta & .911 & .365 \\
X1 & .128 & .140 & & .947 & .004 \\
X2 & .232 & .079 & .228 & 8.881 & .000 \\
X3 & .564 & .064 & .597 & 2.638 & .010 \\
\hline
\end{tabular}


1. Partial test between Price variable (X1) on Customer Satisfaction variable (Y)

Based on the SPSS 18 output obtained t_count $(2,947)>$ from t table $(1,663), \mathrm{H} 2$ is received at a significance level of $5 \%$ so that it can be concluded that partially Price variable (X1) significantly influences the Customer Satisfaction variable (Y).

2. Partial test between Facility variable (X2) on Customer Satisfaction variable (Y)

Based on the SPSS 18 output obtained t_count (8.881)> from $t$ table (1.663), then H3 is accepted at the $5 \%$ significance level so it can be concluded that the Facility variable (X2) partially influences the Customer Satisfaction variable (Y).

3. Partial test between Promotion variable (X3) on Customer Satisfaction variable (Y)

Based on the SPSS 18 output obtained t_count $(2,638)>$ from t_table $(1,663)$, then H4 is accepted at the $5 \%$ significance level so it can be concluded that the Promotion variable partially (X3) significantly influences the Customer Satisfaction variable (Y).

\section{CLASSICAL ASSUMPTION TEST RESULTS}

\subsection{Multicollinearity results}

The results of multicollinearity test showed that the tolerance value $>0.1$ and Variance Influence Factor (VIF) $<10$, so that all the independent variables did not occur multicollinearity.

\subsection{Heteroscedasticity results}

The results of heteroscedasticity are known that the points spread randomly both above and below zero on the $\mathrm{Y}$ axis which does not form a particular pattern, it can be concluded that this study does not occur symptoms of heteroscedasticity in the regression model. And this research is feasible to be used and analyzed further.

\subsection{Normality Results}

Based on the Kolmogrov-Smirnov test, the value of Asymp.Sig has a value>0.05. This shows that the data in this study are normally distributed and the regression model is feasible to be used to predict the dependent variable and the independent data is worthy of being used as research.

\section{CONCLUSIONS AND RECOMMENDATIONS}

\subsection{Conclusion}

Based on the data analysis above and the discussion that has been described by the researcher, then this study can be concluded, this is an answer to all the formulation of the problem as follows:

1. Based on the results of multiple linear regression tests simultaneously on the F test, the F test results show 3 independent variables, namely the Price variable, Facility variable, and the Promotion variable have a significant influence on the Customer Satisfaction variable.

2. Based on the results of multiple linear regression tests, the price variable has a value of $t$ _count $(2.947)>$ from t_table (1.663), then H2 is accepted at the 5\% significance level so it can be concluded that the price variable partially has a significant effect on the Customer Satisfaction variable.

3. Based on the results of multiple linear regression, the facility variable has a value of t_count $(8.881)>$ from t_table $(1,663)$, then $\mathrm{H} 3$ is accepted at a significance level of $5 \%$ so it can be concluded that the Facility variable partially has a significant effect on the Customer Satisfaction variable.

4. Based on the results of multiple linear regression, the promotion variable has a value of $t$ _count $(2,638)>$ from t_table $(1,663)$, then $\mathrm{H} 4$ is accepted at a significance level of $5 \%$ so it can be concluded that the Promotion variable partially influences the Customer Satisfaction variable.

\subsection{Suggestion}

Based on the results of the above analysis, the variable prices, facilities, and promotions have a significant effect on customer satisfaction. Then the advice that will be given to the Grand Darmo Suite Hotel is as follows:

1. It is expected that the management of the Grand Darmo Suite Hotel will further improve prices, facilities and promotions so that the level of customer satisfaction is maintained. 
2. Companies need to also settle on the best price of course by looking at the level of profits that have been adjusted by the company, and adjusting foreign exchange rates.

3. Facilities at service companies are certainly the main thing because with the existence of adequate facilities, it is expected that customers will feel at home and comfortable during their stay at the hotel and will certainly create a customer satisfaction.

\section{REFERENCES}

[1] Tjiptono dan chandra, Service management meningkatkan layanan prima. jakarta: andi, 2012.

[2] P. and G. A. Kotler, Prinsip-prinsipPemasaran. Edisi. 13. Jilid 1. Jakarta: Erlangga, 2012.

[3] Tjiptono, Manajemen Pemasaran dan Analisa Perilaku Konsumen. jakarta: Gramedia, 2001.

[4] F. Tjiptono, pemasaran jasa - prinsip, penerapan, dan penelitian. Yogyakarta: andi Offset, 2014.

[5] F. Tjiptono, service management. mewujudkan layanan prima (I). Yogyakarta: andi, 2008.

[6] philip Kotler, Manajemen Pemasaran Jilid 1 (Kedua Bela). jakarta: PT. Idex, 2009.

[7] dkk Tjiptono, Fandy, Stategi pemasaran (Ketiga). Yogyakarta: andi, 2008.

[8] mardalis, Metode Penelitian Suatu Pendekatan Proposal, Cet. VI. jakarta: Bumi Aksara, 2003. 